\title{
Correction to: Minicircle DNA vector expressing interferon-lambda-3 inhibits hepatitis B virus replication and expression in hepatocyte-derived cell line
}

Xiaoyan Guo ${ }^{1 \dagger}$, Dianke Chen ${ }^{2+}$, Qingxian Cai ${ }^{3}$, Zhanlian Huang ${ }^{1}$, Wenxiong Xu', Liang Peng ${ }^{1 *}$ and Ping Chen ${ }^{4^{*}}$

\section{Correction to: BMC Mol Cell Biol \\ https://doi.org/10.1186/s12860-020-00250-9}

Following publication of the original article [1], the authors reported an error that occurred during the production process. The $\alpha$ (alpha) character was erroneously omitted in the PDF version of the article.

The original article [1] has been corrected.

\begin{abstract}
Author details
${ }^{1}$ Department of Infectious Diseases, The Third Affiliated Hospital of Sun Yat-Sen University, Guangzhou, China. ${ }^{2}$ Department of Medical Oncology, The Sixth Affiliated Hospital, Sun Yat-Sen University, Guangzhou, China. ${ }^{3}$ Department of Hepatology, The Third People's Hospital of Shenzhen, Shenzhen, China. ${ }^{4}$ Shenzhen Institutes of Advanced Technology, Chinese Academy of Sciences, Shenzhen, China.
\end{abstract}

Published online: 02 March 2020

\section{Reference}

1. Guo X, Chen D, Cai Q, et al. Minicircle DNA vector expressing interferonlambda-3 inhibits hepatitis B virus replication and expression in hepatocytederived cell line. BMC Mol Cell Biol. 2020;21:6 https://doi.org/10.1186/ s12860-020-00250-9.

\footnotetext{
The original article can be found online at https://doi.org/10.1186/s12860020-00250-9

*Correspondence: pliang@mail.sysu.edu.cn; pingchen09@gmail.com

${ }^{+}$Xiaoyan Guo and Dianke Chen contributed equally to this work.

'Department of Infectious Diseases, The Third Affiliated Hospital of Sun Yat-Sen University, Guangzhou, China

${ }^{4}$ Shenzhen Institutes of Advanced Technology, Chinese Academy of Sciences, Shenzhen, China

Full list of author information is available at the end of the article
}

(c) The Author(s). 2020 Open Access This article is licensed under a Creative Commons Attribution 4.0 International License, which permits use, sharing, adaptation, distribution and reproduction in any medium or format, as long as you give appropriate credit to the original author(s) and the source, provide a link to the Creative Commons licence, and indicate if changes were made. The images or other third party material in this article are included in the article's Creative Commons licence, unless indicated otherwise in a credit line to the material. If material is not included in the article's Creative Commons licence and your intended use is not permitted by statutory regulation or exceeds the permitted use, you will need to obtain permission directly from the copyright holder. To view a copy of this licence, visit http://creativecommons.org/licenses/by/4.0/ The Creative Commons Public Domain Dedication waiver (http://creativecommons.org/publicdomain/zero/1.0/) applies to the data made available in this article, unless otherwise stated in a credit line to the data. 